\title{
Development of packaging appearance element design of dadih with Kansei Engineering approach
}

\author{
Delfitriani $^{\mathbf{1}^{*}}$, T Djatna ${ }^{2}$ and E Syamsir ${ }^{3}$ \\ ${ }^{1}$ Agroindustrial Technology Program, Graduate School of Bogor Agricultural \\ University, Bogor, Indonesia \\ ${ }^{2}$ Department of Agroindustrial Technology, Bogor Agricultural University, Bogor, \\ Indonesia \\ ${ }^{3}$ Department of Food Science and Technology, Bogor Agricultural University, Bogor, \\ Indonesia \\ *delfitri70@gmail.com
}

\begin{abstract}
The appearance of a product influences consumer product choice in several ways. The concern of appearance packaging is necessary to encourage consumers to be more interested to consume the Dadih. Hence, improved Dadih packaging is expected to expand its market, extend the shelf life, and ease in consumption. Kansei engineering (KE) is defined as a technology that translates consumer's feeling into design specifications. By using KE, we focused on analyzing and designing product and packaging appearance element design of Dadih based on consumer preferences. This paper was conducted to determine the requirement typical Dadih product main features packaging appearance element design by using KE. In order to determine the requirement typical Dadih product main features, Principal component analysis (PCA) was used as the methods to determine the product and packaging appearance element design. The result showed design support to find out the optimal combination product form element in term of sets of given product strategies. Finally, it was expected that using this methods will obtain optimal formulation on design of Dadih product on each personality type, so as to product attractive, innovative, preferred Dadih by consumer as well as minimize the risk of failure of new product design on the market.
\end{abstract}

\section{Introduction}

Fermented milk has been developed as a source of healthy food since long time ago. Development of fermentation products in most countries in the world is based on its contribution to health. One type of fermented milk from West Sumatera, is called Dadih. The Dadih is likely to be developed as a functional food. The isolated bacteria in the Dadih shows there are 36 strains of dominant lactic acid bacteria. Buffalo population growth as the main raw material of Dadih production has declined in quantity and geography. In 2005, the Indonesian buffalo population was 2428 million head, while the population in 1941, 3118 million heads. The production capacity of the buffalo dairy business is relatively low, 1.5 - 2.5 liters per day. It does not have any economic sense when compared with cow dairy production reaching 20 liters per day (1) Such conditions result in a decrease of Dadih production and clearly threatening the existence of the Dadih as a geographical specific products in West Sumatera. One effort in ensuring the existence, by isolating lactic acid bacteria in the Dadih of 
West Sumatera. The results showed that Lactobacillus plantarum as the most dominant bacteria. Furthermore, the dominant bacteria then be used as starter in the production of raw milk Dadih with cow dairy and the result shows that the cow dairy Dadih has characteristics resembling to the buffalo milk Dadih.

Product development of buffalo milk Dadih by replacing the main raw material is necessary due to the diminishing availability of buffalo milk. Dairy cows with quite a lot availability in Indonesia is more than buffalo milk is an alternative raw material that can be used. Consequently, the processing of the Dadih needs to be modified to produce milk Dadih with characteristics similar to buffalo milk (2) The Dadih is a yellowish white color, aroma and has a sour taste and distinctive look traditional food that allegedly due to the influence of bamboo as its packaging. The difficulty of marketing and the shelf life of the Dadih product in bamboo tubes is one of constraint in its market expansion. Therefore, modifications of packaging is expected to improve the marketing of the Dadih and lengthen its shelf life as other fermented milk (3).

Appearance of an object is the result of a complex interaction on the object, the optical characteristics of the object, and human perception. The quality of a product's appearance is psychologically related to its expected performance and useful life. It therefore determines its reception by potential purchasers. All manufacturing industries are concerned with the appearance of their products. Appearance involves all visual phenomena such as color, gloss, shape, texture, shininess, haze, and translucency that characterize objects. All other things being equal, when consumer have a choice, they buy what looks best. Appearance is the foremost and most impressive product message (4).

Appearance of Dadih products development changes through time. The Dadih was initially packaged in a non-toxic plastic tube. Research on cow's milk Dadih packed in a plastic tube showed a shelf life of up to 15 days at room temperature. The use of packaging other than bamboo packaging is already being developed, such as the use of plastic cups, pottery and flexible packaging. It is necessary to encourage consumers to be more interested to consume the Dadih and improve the product image not only as a local product but also as beneficial products for health. Hence, improved packaging is expected to expand its market, extend the shelf life, and ease in consumption (5).

Product design has been recognized as an opportunity for differential advantage in the market place. A number of companies successfully focus on product design as a competitive tool. The appearance of a product influences consumer product choice in several ways. The design of a product determines consumers' first impression of the product and can quickly communicate product advantage. In addition, the design of a product will generate consumer inferences regarding several product attributes. Furthermore, product appearance can provide value in itself; many people like to buy a product that looks aesthetically pleasing. As the influence of product design on consumer evaluation is often complex, it is difficult to decide upon during the product development process. For example, a product with bright colors may be valued aesthetically, but these same colors may give consumers the idea that the product is of low quality (6).

Methods of Kansei Engineering (KE) can be used to explore consumer impressions on aspects of the uniqueness of a product that is represented by the Kansei words (KW). Dimensions of KW itself is a representation of the consumer's perception of a product in terms of affective. The approach is very well used to dig a consumer impression of the Dadih product through KW. This information will become a reference for determining the Dadih product design strategy to be developed. In the previous study KE has been applied in a wide variety of product design, such as rattan wood design (7) the Balinese aromatherapy product (8), ecotourism mobile applications (9), Bogor pickled security (10), and food service in aircraft (11). It is expected that using this method will obtain optimal formulation on the design of new Dadih products, so as to produce attractive, innovative, preferred Dadih by consumers with regard to aspects of the uniqueness that characterizes the Dadih product as well as minimize the risk of failure of new product design on the market. The objectives of this paper is to determine the requirement typical packaging appearance element design of Dadih by using KE which 
could fulfill customer satisfaction. This paper is constructed as follow described of the methodology in section 2, present the result and discussion in section 3, and main conclusion in section 4 .

\section{Methods}

\subsection{Framework}

In this paper, Dadih product has been chosen as a product domain to develop. The system framework is represented in Figure 1. The system began with identifying system entity. Afterward, the production system was analyzed and designed by using KE. Finally, the formulation models were determined for every stage of the system process.

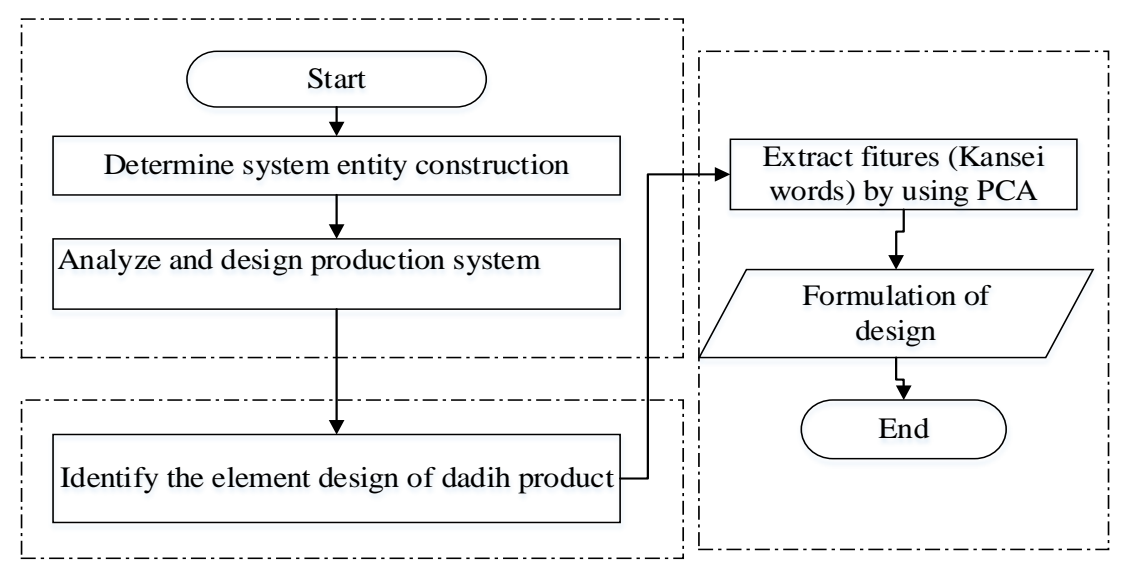

Figure 1. System framework.

\subsection{Identification system}

System is an integrated set of interoperable elements that working synergistically to perform value added processing and to satisfy the user with a specified outcome (12). First step which is done to design a system is to define system entity construction. Next step analyzed the need and used case related to human requirement by taking the entities system. Steps for analysis initiated with a process hierarchy diagram (PHD) as a guidance to work breakdown structure. PHD is the flow process diagram that depict to the highest tasking level consists of a series of process and decomposition of task interconnection link. For each level of decomposition process can be described at many functions of business.

Business process diagram (BPD) describes a system at highest level. BPD facilitates the graphical display from the data flow between processes at each level of built system. BPD has fewer notations and it is usually used by the user to analyze the flow system process that will be developed. Business process is modeled in BPMN 2.0. It is started from the making of simple flow chart, identification stakeholder, granting information related roles, process, data and information to description, therefore it can be analyzed and simulated. System analysis is conducted for parse a system be resolved into components so it the interactions between components and its environment can be seen.

\subsection{Determination of product and packaging appearance elements design}

2.3.1 Collection of KW. Phase of KW collection is performed by searching in internet, related literature, interviews with consumer of relevant product design concepts. After these words obtained through the questionnaire, it will be reduced using Term Frequency-Inverse Document Frequency (TF-IDF) to generate the KW that can represent the whole word obtained. Overall this word pairs obtained will be an indicator to evaluate $\mathrm{KW}$ to a product. 
2.3.2 Classifying elements design of packaging. Sample products are grouped and reduced in morphological analysis. Application of the method to identify the similarity and dissimilarity in every sample collected. The similarity matrix created and performed grouping on samples that have the highest similarity. This process is iterated continually to obtain the hierarchical structure of the sample group of products that have been collected (13).

2.3.3 Evaluation of KW. Evaluation of KW are obtained using a questionnaire carried out by the method of semantic differential scale. Determination of semantic differential scale is the right thing to perform to facilitate the respondent assessment and prevent consumers to bring neutral value on the object being evaluated (14). This questionnaire will be a tool for the respondents to evaluate samples of existing products. The results of the obtained were extracted using the Principal Component Analysis (PCA) method. Feature extraction is performed to extract the KW into the design concept. The PCA method used in this step is a statistical technique for extracting information large sets of variables correlation into several main components, without reducing the significance of the variability in the data set (15).

\section{Result and Discussion}

\subsection{Analysis and design of dadih production system}

This paper begins by analyzing the production system of Dadih product by using KE to determine system entity. System entity consists of inputs, process, resources, stakeholders, controls, roles, missions and objectives, threats, and outputs. Based on the construction, in Figure 2 shows system entity of Dadih product.

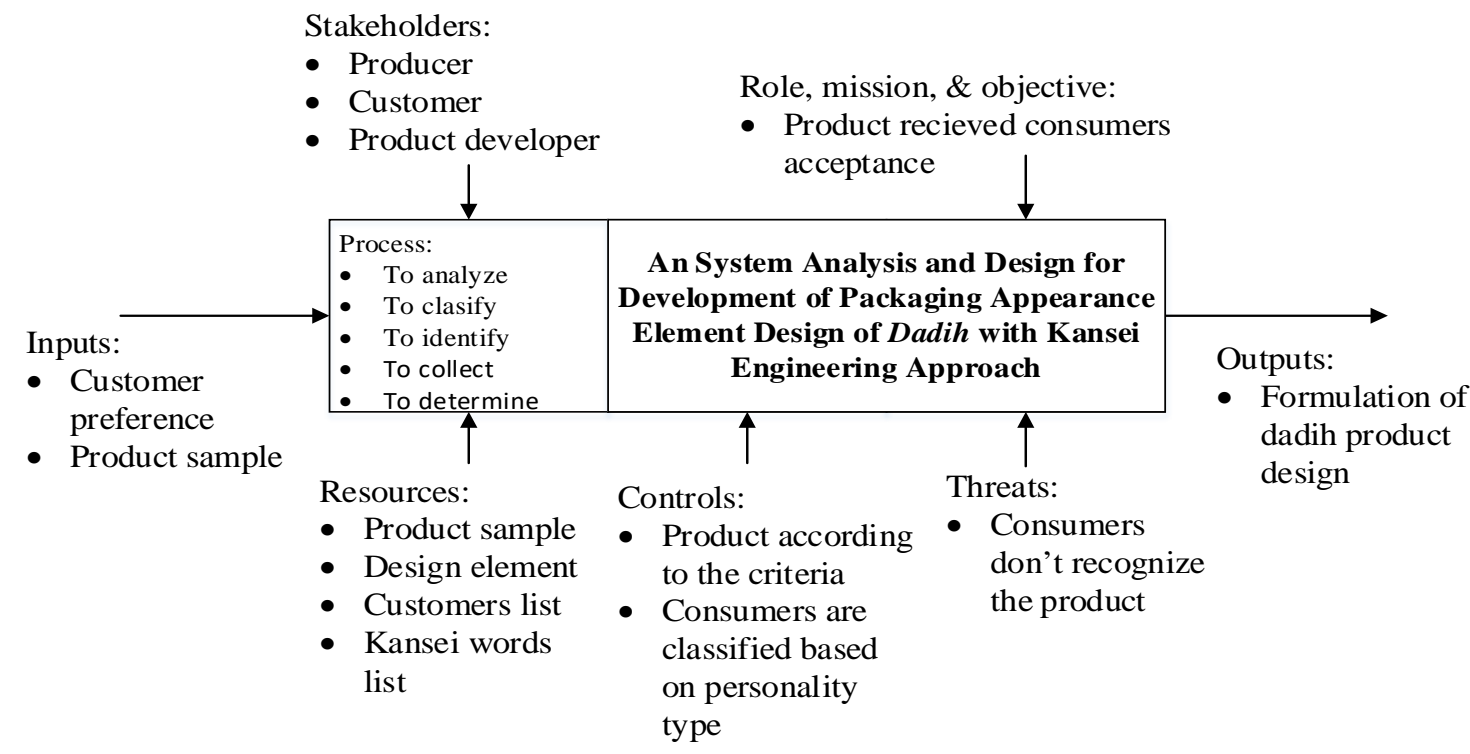

Figure 2. System entity construction of Dadih product.

\subsection{Determination of Packaging Appearance Elements Design}

3.2.1 Colection of $K W$. In this paper determined the appearance element design of packaging based on KW especially for Dadih product. The KW were derived from collecting questionnaires by 30 respondents and then grouped by using TF-IDF method that is one of the methods of text mining. TFIDF method is a statistic method that is intended to reflect how important a word is to a document in a collection. It is a way to score the importance of words in a KW based on how frequently they appear across multiple questionnaires. In this research, TF-IDF was developed to identify the collection some 
adjective words and to acquire the importance information related the characteristic of product design (16). The result of this section were represented in Table 1 . The KE were from first 35 words with the higher weight.

Table 1. Result of calculation KE by using TF-IDF.

\begin{tabular}{rlr}
\hline No & KW & Weight \\
\hline 1 & Bright & 7.16 \\
2 & Interesting & 5.67 \\
3 & Informative & 7.16 \\
4 & Clear & 2.01 \\
5 & Aesthetic & 7.16 \\
6 & Easy to read & 2.01 \\
7 & Unforgettable & 3.18 \\
8 & Clear picture & 3.18 \\
9 & Complex & 3.18 \\
10 & Safe & 5.67 \\
11 & Practical & 7.16 \\
12 & Innovative & 7.16 \\
13 & Attractive & 3.18 \\
\hline
\end{tabular}

\begin{tabular}{rlr}
\hline No & KW & Weight \\
\hline 14 & Communicative & 3.18 \\
15 & Environmentally friendly & 6.01 \\
16 & Efficient & 6.01 \\
17 & Preferably & 2.01 \\
18 & Trendy & 2.01 \\
19 & Luxury & 2.01 \\
20 & Flexible & 5.67 \\
21 & Effective & 7.16 \\
22 & Delight & 2.01 \\
23 & Durable & 2.01 \\
24 & Unique & 15.79 \\
25 & Proportional & 5.67 \\
26 & Ergonomic & 2.01 \\
\hline
\end{tabular}

\begin{tabular}{rlr}
\hline No & KW & \multicolumn{1}{c}{ Weight } \\
\hline 27 & Diverse & 2.01 \\
28 & Strong & 2.01 \\
29 & Modern & 10.65 \\
30 & Lifestyle & 4.19 \\
31 & Creative & 5.67 \\
32 & Beauty & 2.01 \\
33 & Elegant & 2.01 \\
34 & Functional & 2.01 \\
35 & Economic & 8.89 \\
\hline
\end{tabular}

3.2.2 Element design of Dadih packaging. The Product design was identified by collecting 23 Dadih product and then classified by their similarity. Table 2 shows identification of Dadih elements design. This samples collected based on observation of the whole world via Internet and direct market survey. The packaging samples consider to similarity of color, typography, shape, material, label, transparency, volume, and ratio between height and weight. The respondents were selected by purposive and judgement sampling technique. Respondents the research are thirty customers who ever buy a Dadih and they always observe the packaging before they buying the product.

Table 2. Identification the packaging apperance element design.

\begin{tabular}{|c|c|c|c|c|c|c|}
\hline \multirow{2}{*}{ Design Element } & \multicolumn{6}{|c|}{ Type } \\
\hline & 1 & 2 & 3 & 4 & 5 & 6 \\
\hline Typography & Formal & Custom & None & & & \\
\hline Body color & Bright & White & Dark & & & \\
\hline Top color & Bright & White & Dark & & & \\
\hline Net & Small & Medium & large & & & \\
\hline Top shape & Flat seal & Double seal & Concave curve & Parallel line & $\begin{array}{l}\text { Jaggy convex } \\
\text { curve }\end{array}$ & \\
\hline Body shape & Tube & Cup & Cylinder & Punch & Box & Plane \\
\hline Material & Bamboo & Plastic cup & Glass cup & PET & Aluminum & \\
\hline Label position & None & Full & & & & \\
\hline Height : weight & Narrow & Wide & & & & \\
\hline Transparency & $\begin{array}{l}\text { Non- } \\
\text { Transparent }\end{array}$ & Transparent & & & & \\
\hline
\end{tabular}

3.2.3 Evaluation of $K W$. Principal components (F) are computed based on evaluation data of thirty five pair KW (n) (see Table 3) using semantic differential questionnaire contained twenty three parameter (a), each group of data has a F. PCA method used to deciding which of F will be retained according to Kaiser's criterion proposed in A Little Book of R for Multivariate Analysis (17). The result of eigenvalue each $\mathrm{F}$ is shown in Figure 3 . While the value is shown in Table 3 claimed that we should only retain $\mathrm{F}$ for which the most obvious change in slope, the variance is above one, or the total variance can explain at least minimum $80 \%$ (17). 
Figure 3 shown that F1 and F2 have significant slope and they have the variance value is above 1 . Table 3 and Figure 3 are related to a mathematical object, the eigenvalues, which reflect the quality of projection from the $\mathrm{N}$ - dimensional initial table ( $\mathrm{n}=35$ in this sample) to a lower number of dimensions. In this sample, we can see that the first eigenvalue equals 21.683 and represents $61 \%$ of the total variability. This means that if we represent the data on only one axis, we will still be able to see percentage of the total variability of the data.

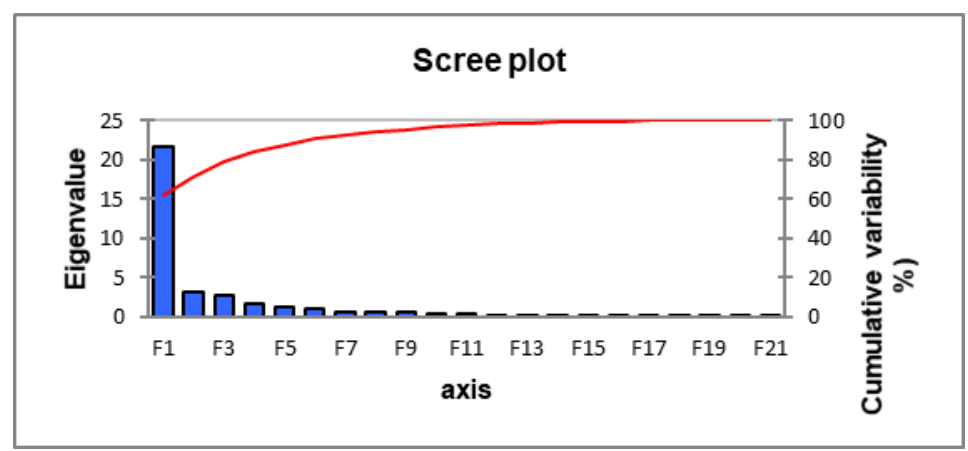

Figure 3. Plot of eigenvalue and variance each principal component (F).

Each eigenvalue corresponds to a factor, and each factor to a one dimension. A factor is a linear combination of the initial variables and all the factors are uncorrelated $(\mathrm{r}=0)$. The first, two or three eigenvalues will correspond to a high \% of the variance, ensuring us that the maps based on the first two or three factors are a good quality projection of the initial multi-dimensional table. In this paper, the first, two factors allow us to represent $71.24 \%$ of the initial variability of the data. This is a good result, but we'll have to be careful when we interpret the maps as some information might be hidden in the next factors. We can see here that although we initially had 35 variables, the number of factors is 21.

The correlation circle is useful in interpreting the meaning of the axes. In this paper the horizontal axis is linked with interesting, informative, clear, aesthetic, easy to read, unforgettable, clear picture, complex, safe, innovative, attractive, communicative, etc. These trends will be helpful in interpreting the next map.

Table 3. The value of variability and cumulative of variances.

\begin{tabular}{|c|c|c|c|c|c|c|c|c|c|c|}
\hline & F1 & $\overline{\mathrm{F} 2}$ & F3 & F4 & F5 & F6 & F7 & F8 & $\ldots$ & F21 \\
\hline Eigenvalue & 21.683 & 3.254 & 2.745 & 1.633 & 1.338 & 1.006 & 0.659 & 0.570 & $\ldots$ & 0.000 \\
\hline Variability (\%) & 61.950 & 9.296 & 7.842 & 4.667 & 3.822 & 2.875 & 1.883 & 1.630 & $\ldots$ & 0.001 \\
\hline Cumulative \% & 61.950 & 71.246 & 79.088 & 83.755 & 87.577 & 90.452 & 92.335 & 93.965 & $\ldots$ & 100.000 \\
\hline
\end{tabular}

The next chart (Figure 4) can be the ultimate goal of the Principal Component Analysis (PCA). It enables to look at the observations on a two-dimensional map, and to identify trends. In Figure 4 can be seen that the Dadih product packaging of A1, E5, E6 are unique, as are the Dadih product packaging of D6 and D7, two states that share common characteristics. The results of this paper can be obtained classification the packaging appearance elements design of Dadih are modern, economical and unique. 


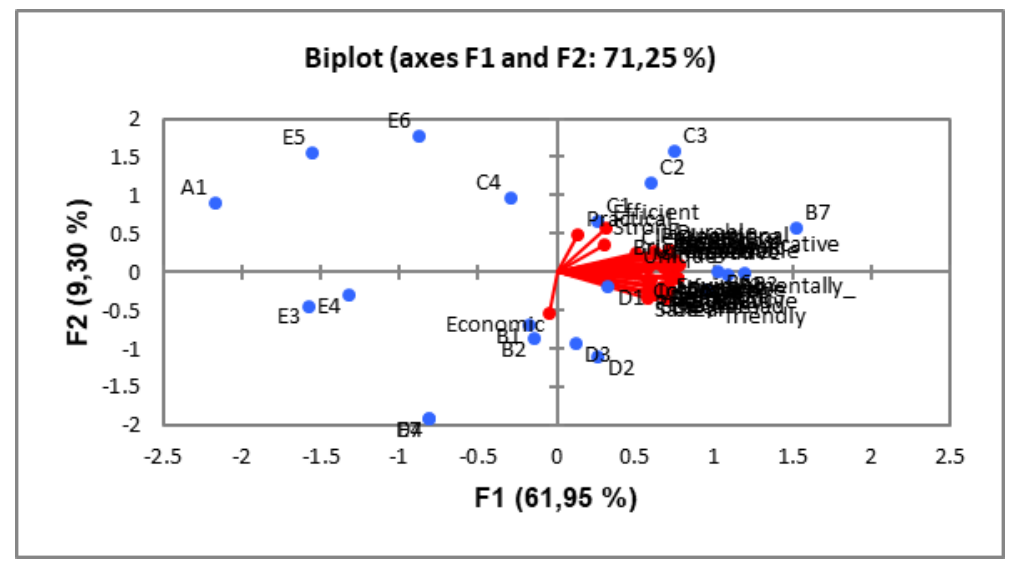

Figure 4. Plot of F Loading and Fscore

Computer-generated mapping of PCA help to extract many indispensable aspect of the product. The maps of $\mathrm{F}$ loadings and $\mathrm{F}$ score can be seen and understand the position of the products. Additionally, we can find the already well-presented KW and one that has not been focused on yet. That kind of information may help to develop a future strategy. Furthermore, combining several different KW is a possible approach to develop innovative products (13).

\section{Conclusion}

From this research we analyzed and designed the Dadih product packaging system based on KE. The system consist of four stakeholders, there are producers, consumers and product developer. From identification of Dadih product, the result of classifying packaging appearance element design into eight categories, there are color, typography, shape, material, label, transparency, volume, and ratio between height and weight. In addition, the color and shape of the packaging are classified by top and body. In this research, we also determine three design strategies for the Dadih product, there are modern, economic and unique. The design of the appearance strategies from the Dadih packaging can be used by designers to make the product packaging design with the peculiarities that characterize Dadih products according to the consumers need while minimizing the risk of failure of Dadih product packaging designs on the market.

\section{References}

1. Zesfin BP, Zulbardi M. Potensi, kemapuan produksi dan reproduksi kerbau sebagai penunjang ketahanan pangan masyarakat Sumatera Barat. In: Seminar Nasional Hari Pangan Sedunia XXVII. Bogor; 2007. p. 256-61.

2. Usmiati S, Broto W, Setiyanto DH, Penelitian BB, Pengembangan D, Pertanian P. Karakteristik dadih susu sapi yang menggunakan starter bakteri probiotik. JITV. 2011;16(12):140-52.

3. Usmiati S, Setiyanto H. Karakteristik dadih menggunakan starter lactobacillus casei selama penyimpanan. In: Seminar Nasional Teknologi Peternakan dan Veteriner. Bogor; 2010. p. 40614.

4. Harold RW. An introduction to appearance analysis. Second Sight. 2001;1-7.

5. Miskiyah, Broto W. Pengaruh kemasan terhadap kualitas dadih susu sapi. Bul Peternak. 2012 Jun 27;35(2):96-106.

6. Creusen MEH, Schoormans JPL. The different roles of product appearance in consumer choice. J Prod Innov Manag. 2005 Jan 1;22(1):63-81.

7. Johan VS. Sistem evaluasi elemen desain kursi rotan menggunakan rekayasa kansei. Institut Pertanian Bogor (IPB); 2012.

8. Santosa IBDY. Pengembangan desain produk aromaterapi khas bali berbasis kansei engineering dan tipe kepribadian konsumen. Institut Pertanian Bogor; 2015. 
9. Aktivia R. Rekayasa visual usability pada aplikasi mobile ekowisata menggunakan kansei engineering. Institut Pertanian Bogor (IPB); 2015.

10. Sari NP. Desain afektif untuk kemasan asinan bogor. Institut Pertanian Bogor (IPB); 2015.

11. Hidayat HH. Desain pelayanan makanan yang menyenangkan dalam pesawat berdasarkan kepribadian penumpang menggunakan hybrid kansei engineering. Institut Pertanian Bogor (IPB); 2015.

12. Wasson CS. System analysis, design, and development: concepts, principles, and practices. Wiley-Interscience; 2006. 818 p.

13. Nagamachi M. Kansei/affective engineering. CRC Press; 2011.

14. Sarjono H, Julianita W. SPSS vs LISREL: sebuah pengantar, aplikasi untuk riset. Jakarta: Salemba Empat; 2011.

15. Dai Y, Chakraborty B, Shi M. Kansei engineering and soft computing: theory and practice. New York: Engineering Science Reference; 2011. 412 p.

16. Kurniati WD. Packaging design of natural beverage based on KE and customer attitude: A case in CTC black tea powder. Institut Pertanian Bogor; 2016.

17. Coghlan A. A little book of $\mathrm{R}$ for multivariate analysis [Internet]. Cambridge: Wellcome Trust Sanger Institute; 2017. Available from: https://media.readthedocs.org/pdf/little-book-of-r-formultivariate-analysis/latest/little-book-of-r-for-multivariate-analysis.pdf 